\title{
Analisis Penerapan Pembiayaan Al-Qordul Hasan di DI BMT NU Bungatan Situbondo
}

\author{
Sofian Syaiful Rizal \\ Universitas Nurul Jadid \\ sofiansyaifulrizal@gmail.com
}

\section{Moch Alfien Maulana \\ Universitas Nurul Jadid \\ dcpien24@gmail.com}

\begin{abstract}
Abstrak Baitul Maal wat Tamwil (BMT) atau disebut juga dengan "Koperasi Syariah", merupakan lembaga keuangan syariah yang berfungsi menghimpun dan menyalurkan dana kepada anggotanya dan biasanya beroperasi dalam skala mikro. Salah satu produk yang menjadi kajian dalam penelitian ini adalah produk al-qardh dan al-qardhul hasan. Alqardh dan al-qardhul hasan adalah suatu sistem yang berkaitan dengan segala bentuk pinjaman tanpa imbalan yang berasaskan pada hukum alqardh. Qardhul Hasan adalah salah satu produk keuangan Islam, yang juga merupakan buah dari semangat Ta'awun 'ala al-Birr, dimana pembiayaan diberikan tanpa syarat dan pengharapan laba, namun dilandasi oleh semangat tolong menolong antar sesama. Studi ini menggunakan metode deskriptif kualitatif, yaitu dengan melakukan wawancara. Setelah diakukan proses penelitian, maka kesimpulannya adalah dalam proses penerapan pembiayaan, ada beberapa tahapan dalam proses pemberian pembiayaan Al Qordu Hasan di koperasi, yang pertama permohonan pembiayaan, kedua analisa nasabah, ketiga pendidikan dasar dari pihak koperasi, keempat Pencairan Dana Pembiayaan Qardul Hasan, kelima pencairan dana. Dalam penerapan pembiayaan al qordul hasan disini menggunakan LASISMA (layanan berbasis jama'ah)
\end{abstract}

Kata Kunci Al Qordul Hasan, Penerapan Pembiayaan

\section{PENDAHULUAN}

Baitul Maal wat Tamwil (BMT) atau disebut juga dengan "Koperasi Syariah" merupakan lembaga keuangan syariah yang berfungsi menghimpun dan menyalurkan dana kepada anggotanya dan biasanya beroperasi dalam skala mikro. Baitul Mall Wat Tanwil sebenarnya merupakan dua kelembagaan yang menjadi satu yaitu lembaga "Baitul Mall" dan lembaga "Baitul Tamwil" Baitulmaal merupakan istilah untuk organisasi yang berperan dalam mengumpulkan dan menyalurkan dana non profit, seperti zakat, infak dan sedekah. Baitultamwil merupakan istilah untuk organisasi yang mengumpulkan dan menyalurkan dana komersial. dengan demikian BMT mempunyai peran ganda yaitu fungsi sosial dan fungsi komersial.(Hapsari \& Saputro, 2017) 
Salah satu Lembaga Keuangan Syariah yang menyalurkan dana kepada masyarakat adalah koperasi syariah. Dalam operasionalnya, koprasi syariah tidak saja berperan menyalurkan dana kepada para masyarakat mampu dan kalangan menengah yang mempunyai jaminan saja, akan tetapi juga menyalurkan dana kepada pengusaha kecil atau masyarakat kurang mampu yang mempunyai potensi keterampilan usaha. Yang menjadi keunggulan koprasi syariah dari aktivitas sosialnya adalah adanya skim pembiayaan Al Qardul Hasan (Riswandi, 2015).

Peran umum BMT yang dilakukan adalah melakukan pembiayaan dan pendanaan yang berdasarkan sistem syariah. Peran ini menegaskan arti penting prinsip-prinsip syariah dalam kehidupan ekonomi masyarakat. Sebagai lembaga keuangan syariah yang bersentuhan langsung dengan masyarakat kecil, maka BMT mempunyai tugas penting dalam mengemban misi keislaman dalam aspek kehidupanmasyarakat(Yaqin, 2020).

Salah satu produk yang menjadi kajian dalam penelitian ini adalah produk Al-Qardh dan Al-Qardhul Hasan. Al-Qardh dan al-Qardhul Hasan adalah suatu sistem yang berkaitan dengan segala bentuk pinjaman tanpa imbalan yang berasaskan pada hukum $\mathrm{Al}$ Qardh. Istilah Alqardh, menurut bahasa Arab berarti pinjaman, yaitu meminjamkan sesuatu kepada orang lain, di mana pihak yang dipinjami sebenarnya tidak ada kewajiban mengembalikan. Para ulama fikih, sepakat bahwa Al-Qardh boleh dilakukan, atas dasar bahwa tabiat manusia tidak bisa hidup tanpa pertolongan dan bantuan saudaranya. Tidak ada seorang pun yang memiliki segala sesuatu yang dibutuhkannya untuk kehidupan. Oleh karena itu, pinjam meminjam sudah menjadi satu bagian dari kehidupan di dunia, dan Islam adalah agama yang sangat memperhatikan segenap kebutuhan umatnya (Purwadi, 2015).

Qardhul Hasan adalah salah satu produk keuangan Islam, yang juga merupakan buah dari semangat ta'awun ala birr, dimana pembiayaan diberikan tanpa syarat dan pengharapan laba, namun dilandasi oleh semangat tolong menolong antar sesama. Dalam proses pembiayaan Qardhul Hasan BMT bertindak sebagai pemberi modal atau pihak yang meminjamkan kepada pihak yang ingin meminjam (Ashal \& Nanda, 2018).

Hasil Penelitian Sukma et al, (2019) menjelaskan, perbankan syariah dalam mengimplementasikan akad qardh hasan tersebut merupakan salah satu bentuk tolong menolong kepada masyarakat dan memberikan banyak manfaat.

Menurut penelitian Ashal \& Nanda (2018), Skema Pembiayaan Qardul Hasan membuka dan meningkatkan lapangan kerja bagi masyarakat, meningkatakan kesejahteraan, terbentuknya iklim tolong menolong, dan terciptanya suatu komunitas masyarakat yang sadar bahaya riba serta menolak segala bentuk tawaran pinjaman ribawi.

Dari hasil beberapa penelitian diatas Penting bagi peneliti untuk mengkaji lebih mendalam dan lebih spesifik lokasi terkait bagaimana penerapan Akad Qardul Hasan di BMT NU Bungatan Situbondo serta apa saja manfaat dari penerapan Qardul Hasan di Masyarakat.

Tujuan penelitian ini adalah untuk menganalisis secara parsial bagaimana penerapan pembiayaan Qardul Hasan di BMT NU Bungatan Situbondo Dan manfaat penerapannya di masyarakat.

\section{LANDASAN TEORI}

Menurut ahli fiqih Qardh adalah suatu pinjaman harta yang diberikan kepada pihak yang meminjam yang dikemudian hari peminjam itu wajib atau harus mengembalikan 
harta pinjaman tersebut sesuai dengan jumlah harta yang dipinjamnya ketika peminjam sudah mampu untuk membayarnya(Sukma et al., 2019).

Menurut Fatwa DSN No. 19/DSNMUI/IV/2001, Al-Qardh adalah pinjaman yang diberikan kepada nasabah (muqtaridh) yang memerlukan. Nasabah Al-Qardh wajib mengembalikan jumlah pokok yang diterima pada waktu yang telah disepakati bersama.(Haida, 2016)

Menurut Kompilasi Hukum Ekonomi Syari'ah (KHES) Qardh adalah penyediaan dana atau tagihan antar lembaga keuangan syari'ah dengan pihak peminjam yang mewajibkan pihak peminjam untuk melakukan pembayaran secara tunai atau cicilan dalam jangka waktu tertentu(Sari \& Daipon, 2018).

Qardhul Hasan adalah perjanjian Qardh yang khusus untuk tujuan sosial. Penerima Qardhul Hasan hanya diharuskan untuk melunasi jumlah pokok pinjaman tanpa harus memberikan tambahan apapun.(Sukma et al., 2019)

(Bank muamalat Indonesia) qardul hasan, suatu pembiayaan lunak yang di berikan bank kepada nasabah yang di anggap layak menerima, dengan prioritas bagi pengusaha kecil berpotensial, yang tidak memiliki modal apapun selain kemampuan berusaha.

(Yopie, 2020) menjelaskan pembiayaan Qardh itu, pembiayaan dari bank/LKS dalam bentuk pinjaman tanpa imbalan, dengen nasabah mengembalikan pokok pinjaman secara sekaligus atau cicilan, dengan jangka waktu tertentu. Si nasabah di perbolehkan mengembalikan melebihi pinjaman pokok nya atas dasar rasa terimakasih, asal tidak di perjanjikan di awal.

Landasan hukum Al Qardh Ijma' ulama memperbolehkan pelaksanaan qardh / qardhul hasan dengan berlandaskan beberapa acuan sebagai berikut (Satrio, 2015):

1) Al Qur'an

* "Dan jika ia (orang yang berutang itu) dalam kesulitan, berilah tangguh sampai ia berkela pangan. Dan menyedekahkan (sebagian atau semua utang) itu, lebih baik bagimu, jika kamu mengetahui" (QS Al-Baqarah - Ayat 280)

* "Jika kamu meminjamkan kepada Allah pinjaman yang baik, niscaya Allah melipatgandakan balasannya kepadamu dan mengampuni kamu, dan Allah Maha Pembalas Jasa lagi Maha Mengetahui” ( QS At Taghabun :11)

2) Dalil Sunnah : Hadits diriwayatkan oleh Ibnu Mas'ud, ia berkata bahwa Nabi SAW bersabda: "Tidaklah seorang muslim memberi pinjaman kepada muslim lain dua kali, melainkan pinjaman itu seperti sedekah sekali” (HR Ibnu Majah dan Ibnu Hibban)

Adapun sumber pendanaan Qardhul Hasan diperoleh dari beberpa sumber, yaitu: dari modal bank itu sendiri, dan dari dana meragukan, yang diiterima dari bunga bank koresponden bank konvensional yang tidak dapat dihindarkan, dan juga dari dana pinalti bank kepada nasabah.(Marwiyah, 2018)

\section{METODOLOGI PENELITIAN}

Penelitian ini menggunakan pendekatan kualitatif deskriptif, yaitu dengan melakukan wawancara. Pengamatan secara langsung yang di gunakan dalam penelitian. Penelitian deskriptif menurut Sugiyono yaitu penelitian yang dilakukan untuk menggambarkan sesuatu yang telah berlangsung pada saat riset dilakukan atau 
menggambarkan fenomena-fenomena yang terjadi disekitar objek penelitian untuk mengetahui nilai variabel mandiri(Sugiyono, 2011).

Penelitian ini di lakukan pada koperasi simpan pinjam pembiayaan syari'ah yaitu BMT NU bungatan Situbondo. Mengapa BMT sebagai objek penelitian karena pembahasannya tentang suatu hal yang berkaitan dengan BMT. dimana suatu lembaga keuangan berbentuk koperasi syariah yang sesuai dengan umat Islam, penduduk yang mayoritas islam di desa bungatan. Sumber data diperoleh melalui wawancara (in-depth interview), dokumentasi dan observasi terhadap pihak pengelola pembiayaan. Penulis juga melakukan kajian literatur untuk memperkuat analisis bahwa pembiayaan yang dijalankan sesuai dengan skema akad Qardhul Hasan.

\section{HASIL PENELITIAN}

\subsection{Informasi Umum BMT NU Bungatan Situbondo}

KSPPS (Koperasi Simpan Pinjam Dan Pembiayaan Syari'ah) BMT NU Cabang Bungatan lahir berangkat dari sebuah keprihatinan atas kondisi masyarakat Situbondo pada umumnya dan masyarakat kecamatan Bungatan pada khususnya dimana tingkat kesejahteraan masyarakat yang tidak stabil padahal masyarakat Bungatan memiliki etos kerja cukup tinggi.

Melihat kenyataan terjadi di masyarakat kecamatan bungatan situbondo, Pengurus MWC (majelis wakil cabang) NU Bungatan merasa prihatin sehingga merasa perlu untuk membantu memikirkan ekonomi masyarakat. Pada tanggal 12 Januari 2015 Akhirnya Pengurus MWC NU Bungatan menyelenggarakan Musyawarah untuk merancang Program Penguatan Ekonomi Masyarakat. Berbagai ide yang muncul dalam musyawarah masih banyak menimbulkan permasalahan-permasalahan lain, sehingga seringkali setiap pertemuan tidak dapat merumuskan kesimpulan yang kongkrit mengenai langkahlangkah yang akan dilakukan untuk membantu ekonomi masyarakat. Faktor utama yang membuat pembahasan cukup sukar menemukan pemecahan solusi adalah kenyataan kemampuan MWC NU Bungatan dalam segi finansial sehingga banyak ide yang terbuang karena MWC NU Bungatan masih tidak memiliki kemampuan modal finansial (Mahrus Sholeh, Wawancara, 20 November 2020).

Pengurus Direksi KSPP Syariah BMT NU jawa Timur memberi solusi atas kebutuhan MWC NU Bungatan dalam memikirkan ekonomi masyarakat dengan tawaran kerja sama untuk membuka kantor cabang di kecamatan bungatan. Akhirnya seluruh Pengurus MWC NU Bungatan langsung sepakat untuk menindak lanjuti tawaran tersebut dan segera melakukan kunjungan ke Kecamatan Gapura Kabupaten Sumenep yaitu Kantor Pusat KSPP Syari'ah BMT NU Jawa Timur, dalam kunjungan ini MWC NU Bungatan yang diwakili oleh Mahrus (Bletok), Sugianto (Bungatan), Darwis Qodir (Selowogo), Abdul Lasir (Patemon) H. Mahrus Shaleh (Selowogo) dan H. Piu (Selowogo). Dan hasil diskusi kerja sama antar Direksi KSPP Syari'ah dan pengurus MWC NU menyepakati Pada Tanggal 16 Mei 2016 KSPP Syari'ah BMT NU Jawa Timur Cabang Bungatan diresmikan untuk menjadi lembaga keuangan syari'ah dan mulai melayani untuk mengelola keuangan Mayarakat Bungatan pada khususnya dan Mayarakat Situbondo pada umumnya.

Visi \& Misi BMT NU Cabang Bungatan Situbondo:

1. Visi : Terwujudnya KSPP Syar'ah BMT NU yang jujur, amanah dan profesional

2. Misis 
a) Menerapkan prinsip-prinsip syari'at dalam kegiatan ekonomi,

b) Membangun kesadaran masyarakat akan pentinganya prinsip koperasi,

c) Memberikan layanan yang prima kepada seluruh anggota dan mitra,

d) Mencapai pertumbuhan dan hasil usaha yang layak serta proporsional,

e) Turut berperan serta dalam gerakan pengembangan ekonomi syari'ah.

f) Menjadi Cabang KSPP Syari'ah BMT NU percontohan.

\subsection{Penerapan Pembiayaan Qordul Hasan di BMT NU Bungatan Situbondo}

Ada beberapa tahapan dalam proses pemberian pembiayaan Al Qordu Hasan di BMT NU Bungatan (Sukma et al., 2019):

1. Permohonan pembiayaan

Pada tahapan ini, nasabah mengajukan permohonan pembiayaan qardul hasan kepada pihak BMT, dengan membawa beberapa persyaratan yaitu KTP dan Kartu Keluarga (KK). Pihak pengelola pembiayaan qardul hasan menyediakan formulir pembentukan forsa. Yang selanjutnya diisi dengan data pribadi nasabah.

\section{Analisis nasabah}

Setelah nasabah mengisi formulir pengajuan pembiayaan, pihak pengelola pembiaayan melakukan disposisi atau meminta izin kepada kepada cabang dan meminta tanda tangan untuk melakukan analisis nasabah. Tujuan analisis nasabah ialah untuk mengetahui layak atau tidaknya nasabah yang akan diberi pembiayaan qardul hasan. seperti lembaga keuangan pada umumnya, BMT NU Bungatan Situbondo juga menerapkan prinsip 5C, yaitu Character, Capacity, Capital, Condition, dan Collateral. Seletah dikakukan analisis nasabah, BMT melakukan rapat komite pembiayaan yang dihadiri oleh kepala cabang, pengelola pembiayaan, dan pihak administrasi. Dalam rapat akan diputuskan nasabah tersebut layak atau tidaknya mendapatkan pembiayaan qardul hasan dan menjadi anggota. yang selajutnya, jika nasabah tersebut diputuskan layak, maka pihak BMT akan menghubungi ketua kelompok dari anggota penerima qardul hasan dan menghubungi nasabah yang bersangkutan bahwa ia bisa lanjut pada tahap selajutnya yaitu pendidikan dasar dari BMT.

3. Pendidikan Dasar (Dikdas) dari pihak BMT

Setelah diputuskan nasabah tersebut layak mendapatkan pembiayaan, maka akan dilakukan dikdas selama tiga hari untuk para anggota kelompok yang baru. Yang memberikan materi pada kegiatan dikdas ini adalah pihak bagian pembiayaan dari BMT. Materi yang diberikan pada anggota baru adalah tentang ke-NUan, produk yang ada di BMT NU, dan pengertian Layanan Berbasis Jamaah (LASISMA), serta asas-asas manfaat BMT NU.

\section{Pencairan Dana Pembiayaan Qardul Hasan}

Setelah dilakukan kegiatan dikdas, diadakan rapat terakhir yang dihadiri kembali oleh kepala cabang, pengelola pembiayaan, dan bagian administrasi. Pada rapat terakhir ini, membahas tentang keputusan jumlah dana yang akan dicairkan kepada anggota baru. Setelah ada keputusan dari kepala cabang, selanjutnya bagian administrasi akan membuat surat keputusan dan mengkonfirmasi kepada nasabah 
yang bersangkutan. Setelah terkonfirmasi, maka pencairan dana akan segera dilakukan.

5. Pencairan dana

Pada proses pencairan dana, nasabah tidak boleh mewakilkannya kepada orang lain. BMT NU Bungatan Situbondo mensyaratkan, yang menerima dana Pembiayaan dan bertanda tangan harus kepala keluarga seperti yang tertera pada kartu keluarga. jika ada halangan tidak hadirnya kepala keluarga, maka yang diperbolehkan bertanda tangan adalah ayah kadung, ibu kandung, dan saudara kandung. Dalam pemberian dana pembiayaan, pihak BMT dan nasabah mengucapkan ijab Qabul. Pihak BMT mengucapkan, "Saya serahkan dana pinjaman ini dari pihak BMT Nu dengan nominal sekian, dengan akad Qardul Hasan”. Dan nasabah menjawab, “iya saya terima".

\subsection{Manfaat Pembiayaan Qordul Hasan di BMT NU Bungatan Situbondo Terhadap Nasabah}

Dengan demikian Qardhul Hassan dapat diartikan sebagai pembiayaan tanpa bunga, yang mana penerima pinjaman hanya mengembalikan pokok pinjaman saja tanpa memberikan imbalan dalam bentuk apapun kepada lembaga, Pembiayaan qardhul hasan diberikan kepada masyarakat yang secara ekonomi masih terbilang rendah untuk digunakan sebagai modal untuk membangun ataupun mengembangkan usaha(Damayanti et al., 2019).

Manfaat pembiayaan Qordul Hasan terhadap nasabah :

a. Memudahkan dalam mendapatkan modal.

b. Tidak mempersulit nasabah dalam peminjaman, karena tidak ada jaminan.

c. membantu permodalan terhadap masyarakat dalam mengembangkan usaha.

d. mengurangi pengangguran pada masyarakat menengah kebawah dengan memberikan pembiayaan qordul hasan untuk menjalankan usaha.

Al-Qardh dan al-Qardhul Hasan merupakan misi sosial perbankan syariah. Misi sosial ini sebagai upaya tanggung jawab sosial perbankan syariah yang bertujuan meningkatkan citra bank, meningkatkan loyalitas masyarakat terhadap bank syariah, dan menumbuhkan pemberdayaan masyarakat. Hal ini, senada dengan dengan perspektif ajaran Agama Islam, bahwa aktivitas finansial dan perbankan dalam dunia modern seperti sekarang ini mengandung dua prinsip, yaitu prinsip al-ta'awun.

Manfaat akad Qardh dalam praktik perbankan syariah banyak sekali diantaranya sebagai berikut (Sukma et al., 2019):

a. Memungkinkan nasabah yang sedang dalam kesulitan mendesak untuk mendapatkan talangan jangka pendek.

b. Al-Qardhul Hasan juga merupakan salah satu ciri pembeda antara bank syariah dan bank konvensional yang di dalamnya terkandung misi sosial, di samping misi komersial.

c. Adanya misi sosial kemasyarakatan ini akan meningkatkan loyalitas masyarakat terhadap bank syariah.

d. Pedagang kecil memperoleh bantuan dari bank syariah untuk mengembangkan usahanya, sehingga misi sosial bagi bank syariah dalam membantu masyarakat miskin. 
e. Dapat mengalihkan pedagang kecil dari ikatan utang rentenir, dengan mendaptkan utang dari bank syariah tanpa bunga.

Manfaat Al -Qardhul Hasan antara lain (Suryadi \& Putri, 2018):

a. Al-Qardhul hasan merupakan fasilitas kredit kebaikan yang diberikan secara cumacuma. Nasabah hanya berkewajiban menanggung biaya materai, biaya notaris dan biaya studi kelayakan. Besarnya tingkat kepedulian BMT terhadap nasabah tanpa memandang tingkat ekonominya. BMT memperlakukan nasabah sebagai mitra usaha yang tidak hanya pertimbangan-pertimbangan bisnis semata, tetapi juga pertimbangan kemanusiaan.

b. Memungkinkan nasabah yang sedang dalam kesulitan mendesak untuk mendapatkan talangan jangka pendek.

c. Adanya misi sosial kemasyarakatan akan meningkatkan citra baik dalam meningkatkan loyalitas terhadap masyarakat.

d. Memerangi kemiskinan dengan membina golongan ekonomi lemah dan tertindas melalui bantuan hibah yang diarahkan secara produktif. Dananya bisa diperoleh dari pinjaman lunak tanpa bunga yaitu al -qardhul hasan.

\section{KESIMPULAN}

pada Tanggal 16 Mei 2016 KSPP Syari'ah BMT NU Jawa Timur Cabang Bungatan diresmikan untuk menjadi lembaga keuangan syari'ah, ada beberapa tahapan dalam proses pemberian pembiayaan Al Qordu Hasan di BMT NU Bungatan, pertama: Permohonan pembiayaan, dimana nasabah mengajukan permohonan pembiayaan qardul hasan kepada pihak BMT, dengan membawa beberapa persyaratan yaitu KTP dan Kartu Keluarga (KK). Kedua: Analisis nasabah, nasabah mengisi formulir pengajuan pembiayaan, pihak pengelola pembiaayan melakukan disposisi atau meminta izin kepada kepada cabang dan meminta tanda tangan untuk melakukan analisis nasabah. Ketiga: Pendidikan Dasar (Dikdas) dari pihak BMT, Setelah diputuskan nasabah tersebut layak mendapatkan pembiayaan, maka akan dilakukan dikdas selama tiga hari untuk para anggota kelompok yang baru. Keempat: Pencairan Dana Pembiayaan Qardul Hasan, diadakan rapat terakhir yang dihadiri kembali oleh kepala cabang, pengelola pembiayaan, dan bagian administrasi.membahas tentang keputusan jumlah dana yang akan dicairkan kepada anggota baru. Kelima: Pencairan dana, Pada proses pencairan dana, nasabah tidak boleh mewakilkannya kepada orang lain. Pembiayaan qardhul hasan diberikan kepada masyarakat yang secara ekonomi masih terbilang rendah untuk digunakan sebagai modal untuk membangun ataupun mengembangkan usaha. Adapun manfaat pembiayaan qordul hasan terhadap nasabah, antara lain: (a) Memudahkan dalam mendapatkan modal, (b) Tidak mempersulit nasabah dalam peminjaman, karena tidak ada jaminan, (c) membantu permodalan terhadap masyarakat dalam mengembangkan usaha, (d) mengurangi pengangguran pada masyarakat menengah kebawah dengan memberikan pembiayaan qordul hasan untuk menjalankan usaha.

\section{DAFTAR PUSTAKA}

Ashal, F. F., \& Nanda, T. S. F. (2018). Transaksi Pembiayaan Qardhul Hasan: Impact Keuangan Islam dalam Ekonomi Ril. Al Tijarah, 4(1), 54-63.

Damayanti, L., Budi, S., \& SEI, M. S. I. (2019). Optimalisasi Qardhul Hasan Sebagai Wujud Pelaksanaan Corporate Social Responsibility (studi kasus bmt mitra 
ummat). IAIN surakarta.

Haida, N. (2016). Mengukur Fungsi Sosial dalam Perkembangan Produk Qardhul Hasan Pada Perbankan Syariah di Indonesia. Al-Amwal: Jurnal Ekonomi Dan Perbankan Syari'ah, 7(2).

Hapsari, L., \& Saputro, E. (2017). Penerapan Fungsi Sosial Pada Baitul Maal Wat Tamwil Dengan Cara Bantuan Modal Sistem Qardhul Hasan Studi Kasus Pada BMT Bina Insan Mandiri Karanganyar. IAIN Surakarta.

Purwadi, M. I. (2014). Al-Qardh dan Al-Qardhul Hasan sebagai Wujud Pelaksanaan Tanggung Jawab Sosial Perbankan Syariah. Jurnal Hukum Ius Quia Iustum, 21(1), 24-42.

Riswandi, D. (2015). Pembiayaan Qardul Hasan Di Bank Syariah Mandiri Kota Mataram. Istinbath: Jurnal Hukum Islam IAIN Mataram, 14(2), 41843.

Sari, F., \& Daipon, D. (2018). Konsep Riba Dalam Kompilasi Hukum Ekonomi Syari’ah (Studi Analisis Teks Kompilasi Hukum Ekonomi Syari;ah Indonesia). ALHURRIYAH: Jurnal Hukum Islam (Alhurriyah Journal Of Islamic Law), 3(2), 203.

Satrio, M. A. (2015). Qardhul Hasan Sebagai Wujud Pelaksanaan CSR dan Kegiatan Filantropi Lembaga Keuangan Syariah Untuk Pemberdayaan Masyarakat. Kajian Bisnis Sekolah Tinggi Ilmu Ekonomi Widya Wiwaha, 23(2), 104-111.

Sukma, F. A., Azizah, N. N., \& Juliani, G. P. (2019). Konsep Dan Implementasi Akad Qardhul Hasan Pada Perbankan Syariah Dan Manfaatnya. Amwaluna: Jurnal Ekonomi Dan Keuangan Syariah, 3(2).

Suryadi, N., \& Putri, Y. R. (2018). Analisis Penerapan Pembiayaan Qardhul Hasan Berdasarkan Psak Syariah Pada Bmt Al Ittihad Rumbai Pekanbaru. Jurnal Tabarru': Islamic Banking and Finance, 1(1), 37-50.

Yaqin, A. (2020). Persepsi Kiai dan Tokoh Nahdhatul Ulama Terhadap Akad dan Produk Al-Qardh Al-Hasan, Rahn dan Hadiah Di Koperasi Simpan Pinjam Pembiayaan Syari'ah Baitul Mal Wa Tamwil (KSPPS BMT NU) Jawa Timur Di Gapura Sumenep. PROFIT: Jurnal Kajian Ekonomi Dan Perbankan Syariah, 4(1).

Ashal, F. F., \& Nanda, T. S. F. (2018). Transaksi Pembiayaan Qardhul Hasan: Impact Keuangan Islam dalam Ekonomi Ril. Al Tijarah, 4(1), 54-63.

Damayanti, L., \& Budi, S., (2019). Optimalisasi Qardhul Hasan Sebagai Wujud Pelaksanaan Corporate Social Responsibility (Studi Kasus BMT Mitra Ummat). IAIN Surakarta.

Haida, N. (2016). Mengukur Fungsi Sosial dalam Perkembangan Produk Qardhul Hasan Pada Perbankan Syariah di Indonesia. Al-Amwal: Jurnal Ekonomi Dan Perbankan Syari'ah, 7(2).

Hapsari, L., \& Saputro, E. (2017). Penerapan Fungsi Sosial Pada Baitul Maal Wat Tamwil Dengan Cara Bantuan Modal Sistem Qardhul Hasan Studi Kasus Pada Bmt Bina Insan Mandiri Karanganyar. IAIN Surakarta.

Marwiyah, Y. (2018). Implementasi Akad Qardhul Hasan Di BMT El Hamid 156 Serang. MUAMALATUNA, 10(2), 51-75.

Purwadi, M. I. (2014). Al-Qardh dan Al-Qardhul Hasan sebagai Wujud Pelaksanaan Tanggung Jawab Sosial Perbankan Syariah. Jurnal Hukum Ius Quia Iustum, 21(1), 24-42.

Riswandi, D. (2015). Pembiayaan Qardul Hasan Di Bank Syariah Mandiri Kota Mataram. Istinbath: Jurnal Hukum Islam IAIN Mataram, 14(2), 41-64. 
Sari, F., \& Daipon, D. (2018). Konsep Riba Dalam Kompilasi Hukum Ekonomi Syari’ah (Studi Analisis Teks Kompilasi Hukum Ekonomi Syari;ah Indonesia). ALHURRIYAH: Jurnal Hukum Islam (ALHURRIYAH JOURNAL OF ISLAMIC $L A W), 3(2), 203$.

Satrio, M. A. (2015). Qardhul Hasan Sebagai Wujud Pelaksanaan CSR dan Kegiatan Filantropi Lembaga Keuangan Syariah Untuk Pemberdayaan Masyarakat. Kajian Bisnis Sekolah Tinggi Ilmu Ekonomi Widya Wiwaha, 23(2), 104-111.

Suryadi, N., \& Putri, Y. R. (2018). Analisis Penerapan Pembiayaan Qardhul Hasan Berdasarkan Psak Syariah Pada BMT Al Ittihad Rumbai Pekanbaru. Jurnal Tabarru': Islamic Banking and Finance, 1(1), 37-50.

Ashal, F. F., \& Nanda, T. S. F. (2018). Transaksi Pembiayaan Qardhul Hasan: Impact Keuangan Islam dalam Ekonomi Ril. Al Tijarah, 4(1), 54-63.

DAMAYANTI, L., Budi, S., \& SEI, M. S. I. (2019). Optimalisasi Qardhul Hasan Sebagai Wujud Pelaksanaan Corporate Social Responsibility (Studi Kasus Bmt Mitra Ummat). IAIN Surakarta.

Haida, N. (2016). Mengukur Fungsi Sosial dalam Perkembangan Produk Qardhul Hasan Pada Perbankan Syariah di Indonesia. Al-Amwal: Jurnal Ekonomi Dan Perbankan Syari'ah, 7(2).

Purwadi, M. I. (2014). Al-Qardh dan Al-Qardhul Hasan sebagai Wujud Pelaksanaan Tanggung Jawab Sosial Perbankan Syariah. Jurnal Hukum Ius Quia Iustum, 21(1), 24-42. 